\title{
Histophatology and ultrastructure of Henneguya caudalongula sp. n. infecting Prochilodus lineatus (Pisces: Prochilodontidae) cultivated in the state of São Paulo, Brazil
}

\author{
Edson AAdriano+ , Sarah Arana*, Nelson SCordeiro**
}

Centro de Pesquisa e Gestão de Recursos Pesqueiros Continentais - Cepta/Ibama, Rod. SP 201, km 6,5, Caixa Postal 64, 13630970 Pirassununga, SP, Brasil *Departamento de Histologia e Embriologia **Departamento de Parasitologia, Instituto de Biologia, Unicamp, Campinas, SP, Brasil

The histological and ultrastructural characteristics of a new species of Henneguya and the host reactions to infection by this species are reported. Henneguya caudalongula $s p$. $n$. was found in the inter and intralamellar regions of the gills of Prochilodus lineatus (Valenciennes, 1836) cultivated at Center for the Research and Management of Continental Fishing Resources located in the municipality of Pirassununga, state of São Paulo, Brazil. The plasmodia were white and round or ellipsoidal and measured 0.2 to $1 \mathrm{~mm}$ in length. The development of the parasite was asynchronous and the mature spores were fusiform, with a total length $71 \pm 1.4 \mu \mathrm{m}$, body length of $16.6 \pm 0.54$ $\mu \mathrm{m}$ and width $4.6 \pm 0.2 \mu \mathrm{m}$. The caudal process was $52.6 \pm 1.5 \mu \mathrm{m}$ long. The polar capsules were elongate (length 6.1 $\pm 0.19 \mu \mathrm{m}$, width $1.6 \pm 0.15 \mu \mathrm{m})$ and of equal size. The polar filament was coiled in 10-11 turns. The prevalence of the parasite was $48.3 \%$ and did not vary significantly with the season or host size.

Key words: Henneguya caudalongula sp. n. - Myxosporea - Prochilodontidae - Prochilodus lineatus - gill - Brazil

Prochilodus lineatus (Valenciennes, 1836) is a detritivorous teleost popularly known as curimba or curimbatá, is widely distributed in South American rivers and attains a relatively large size, with some specimens measuring 75 $\mathrm{cm}$ in length and weighing $8.2 \mathrm{~kg}$ (Godoy 1975). It has a high reproductive capacity, rapid growth, good acceptance on the market and is one of the most consumed fish species in Brazil. Its consumption has led to increased interest in its cultivation in fish farms throughout the country.

Until recently, Myxobolus porofilus Adriano, Aranas, Ceccarelli et Cordeiro, 2002 was the only myxosporean species reported to parasitize $P$. lineatus. However, during a survey of myxosporean parasites of fish species cultivated in Brazil, we found a new species of Henneguya parasitizing the gills of $P$. lineatus. This species is described based on light microscopy, scanning electron microscopy, transmission electron microscopy, and on the histopathological effects produced in the host.

\section{MATERIALS AND METHODS}

Four-month old specimens of $P$. lineatus (curimbatá), Piaractus mesopotamicus (Holmberg, 1887) (pacu), Brycon cephalus (Günther, 1869) (matrinxã) and Leporinus macrocephalus Garavello et Britski, 1988 (piauçu) obtained from artificial reproduction programs were released in a pond at the Center for the Research and Management of Continental Fishing Resources (Cepta/Ibama) located in the municipality of Pirassununga, state of São Paulo, Brazil. Each month, five specimens of each fish species were

+Corresponding autor. E- mail: edapadriano@hotmail.com Received 13 October 2004

Accepted 14 March 2005 examined for the presence of myxozoan parasites from March 2000 to February 2002. Immediately after collection, the fish were transported alive to the laboratory where they were killed by transection of the spinal cord, before being measured and necropsied. Of 120 curimbatá examined, 20 were $7-15 \mathrm{~cm}$ long, 78 were $15.1-25 \mathrm{~cm}$ long and 22 were $25.1-30.5 \mathrm{~cm}$ long.

The parasite was identified according to Lom and Arthur (1989). Measurements from 40 fresh mature spores were obtained using a ocular micrometer and are givem in micrometres $(\mathrm{mm})$ as the mean \pm standard deviation (SD). Smears containing free spores were stained with a Giemsa solution and mounted in low-viscosity mounting medium (Cytoseal ${ }^{\mathrm{TM}}$ ) as permanent preparations. For histological analysis, the gills were fixed in $10 \%$ buffered formalin for $24 \mathrm{~h}$, embedded in paraffin, cut into sections $4 \mu \mathrm{m}$ thick and stained with sirius red (Adriano et al. 2002), haematoxylin and eosin, and PAS. For scanning electron microscopy, free spores were deposited on a coverslip coated with poly-L-lysine and fixed for $2 \mathrm{~h}$ at room temperature with glutaraldehyde in $0.1 \mathrm{M}$ sodium cacodylate buffer ( $\mathrm{pH}$ 7.2). After washing in the same buffer, the preparations were dehydrated in ethanol, critical point dried by $\mathrm{CO}_{2}$, coated with metallic gold and examined in JEOL JSM 35 microscope operated at $15 \mathrm{kV}$. For transmission electron microscopy, fragments of gills containing plasmodia were fixed in $2.5 \%$ glutaraldeyde in cacodylate buffer $(2 \mathrm{~h})$, dehydrated in increasing concentrations of acetone and embedded in Epon-Araldite resin. Ultrathin sections double stained with uranyl acetate and lead citrate were examined in a LEO 906 electron microscope operated at $60 \mathrm{kV}$.

The chemical and physical properties of the pond water, including dissolved oxygen levels and temperature, were measured daily. Other properties, such as alkalinity, $\mathrm{pH}, \mathrm{NH}_{3}$ and hardness, were measured weekly. Pearson's 
correlation was used to determine whether there was any correlation between the chemical and physical characteristics of the water and the prevalence of the parasite. The effect of season and host size on prevalence was tested using the $\chi^{2}$ test, with the level of significance set at $\mathrm{p}<0.05$.

\section{RESULTS}

Of the four fish species studied, only specimens of $P$. lineatus had the parasite. Fifty-eight of 120 specimens examined (48.3\%) had plasmodia of an undescribed species of Henneguya in their gills.

The parasite was found throughout the duration of the study and its occurrence did not vary significantly from one season to another $\left(\chi^{2}=10.82, \mathrm{df}=7\right.$, ns: non significant) or with host size $\left(\chi^{2}=0.39, \mathrm{df}=2, \mathrm{~ns}\right)$. There was no correlation between the prevalence of the parasite and the chemical and physical characteristics of the water, such as alkalinity $(r=0.0339: p=0.8723), p H(r=0.3745$ : $\mathrm{p}=0.0651)$, hardness $(\mathrm{r}=-0.0326: \mathrm{p}=0.8770), \mathrm{NH}_{3}(\mathrm{r}=$ $-0.0406: p=0.8472)$ and temperature $(r=0.1368: p=0.5145)$, but there was a significant correlation with the dissolved oxygen levels $(r=0.5244: p=0.0071)$.

\section{Henneguya caudalongula sp. $\mathrm{n}$.}

Figs 1-4

Description

Vegetative stage: plasmodia white, round or ellipsoidal, up to $1 \mathrm{~mm}$ long. Development asynchronous; generative cells, sporoblasts and mature spores seen in the same plasmodium (Fig. 2B). Plasmodia surrounded by capsule of connective tissue (Figs 1D, 2A, B). The plasmodial wall intraconnected with thin plasmodial ectoplasmic zone through numerous pinocytotic canals terminating in pinocytotic vesicles (Fig. 2A).

Spores: electron microscopy showed spores with binucleate sporoplasm containing a few dark, randomly scattered sporoplamosomes (Figs 2C, D). Space between the polar capsules and valve on two sides of the spore with electron-dense spherical inclusions (Fig. 3A). Mature spores fusiform in face view, total length $71 \pm 1.4$, body length $16.6 \pm 0.54$ and width $4.6 \pm 0.2$ (Fig. 1A). Valve surfaces smooth and prolonged by caudal process $52.6 \pm 1.5$ long (Fig. 3D). Polar capsules elongate (length $6.1 \pm 0.2$, width $1.6 \pm 0.2 \mu \mathrm{m})$ and of equal size. Polar filaments thin and coiled in 10-11 turns aligned perpendicularly to longitudinal axis of capsule (Fig. 3C).

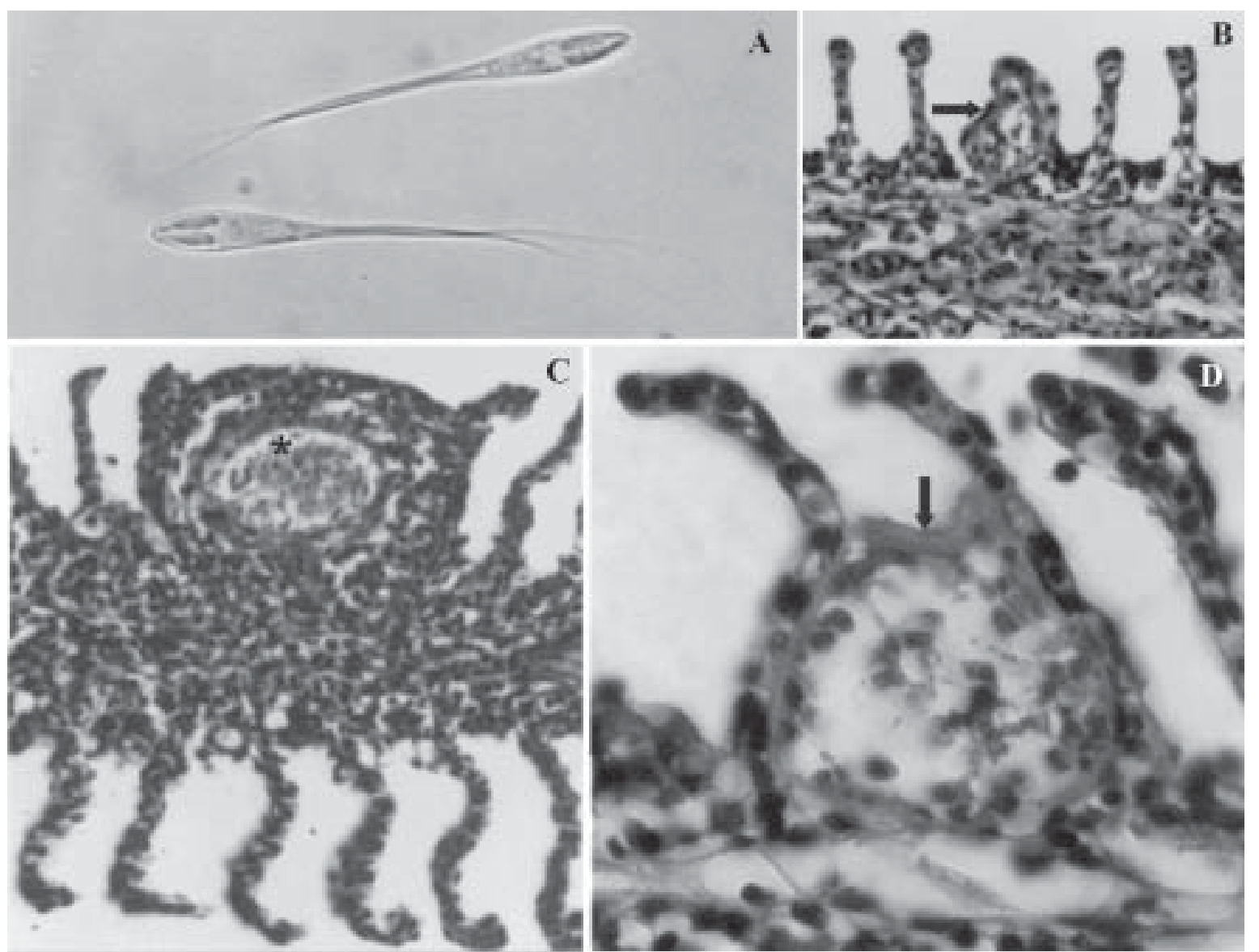

Fig. 1: Heneguya caudalongula sp. n. from Prochilodus lineatus. A: spores in a fresh preparation. 3700×; B-D: histological sections of gills. H \& E staining; B: young plasmodium in the intralamellar epithelium (arrow). $1160 \times$; C: interlamellar pasmodium*. Note the severe hyperplasia of the epithelial cells. $1640 \times$; D: young plasmodium in the interlamellar epithelium. Note the collagen capsule surrounding the plasmodium (arrow). $3400 \times$. 
Type host: P. lineatus (Valenciennes, 1836) (Pisces, Characiformes, Prochilodontidae).

Site of infection: gills (the interlamellar and intralamellar space).

Prevalence: 58/120 (48.3\%) of P. lineatus were infected.

Type locality: Center for the Research and Management of Continental Fishing Resources Cepta/Ibama, Pirassununga, state of São Paulo, Brazil.

Type material: slides with stained spores (syntype) have been deposited in the collection of the Museum of Natural History, Institute of Biology, state University of Campinas (Unicamp), state of São Paulo, Brazil (accession numbers ZUEC 16 and 17).

Etymology: the specific name is a combination of the Latin substantive cauda (= tail) and of the Latin adjective longula (= long) in reference to the length of the caudal process.

Histopathology: the parasite developed in the interlamellar and intralamellar gill regions (Figs 1B, D). The plasmodia were surrounded by a thin collagen capsule (Fig. 1D). In an advanced stage, the infection caused deformation of the lamellar structures, pushed aside the neighbouring gill lamellae, produced lamellar fusion, and caused severe hyperplasia in epithelial cells, but not mucous cells (Fig. 1C). No inflammatory reaction was observed in the infected fish.

\section{DISCUSSION}

Spore morphology and dimensions of $\mathrm{H}$. caudalongula were compared with all Henneguya species identified in South American fishes. Only H. piaractus Martins et Souza, 1997, which parasitizes P. mesopotamicus and $\mathrm{H}$. pilosa Azevedo et Matos, 2003, which infects Serrasalmus altuvei, showed a similar morphology to $H$. caudalongula (Table). However, H. caudalongula has a greater spore body length $(16.6 \mu \mathrm{m})$ than H. piaractus $(12.7 \mu \mathrm{m})$ but smaller than H. pilosa $(21.1$ $\mu \mathrm{m})$. The total length of $H$. caudalongula $(71 \mu \mathrm{m})$ is greater than that of $H$. piaractus and $H$. pilosa $(52.5 \mu \mathrm{m}$ and 54.2 $\mu \mathrm{m}$, respectively). In addition, $H$. caudalongula has $10-$ 11 turns in the polar filament, while $H$. piaractus has 8-9 and $H$. pilosa 11-13. In addition to these differences, ul-

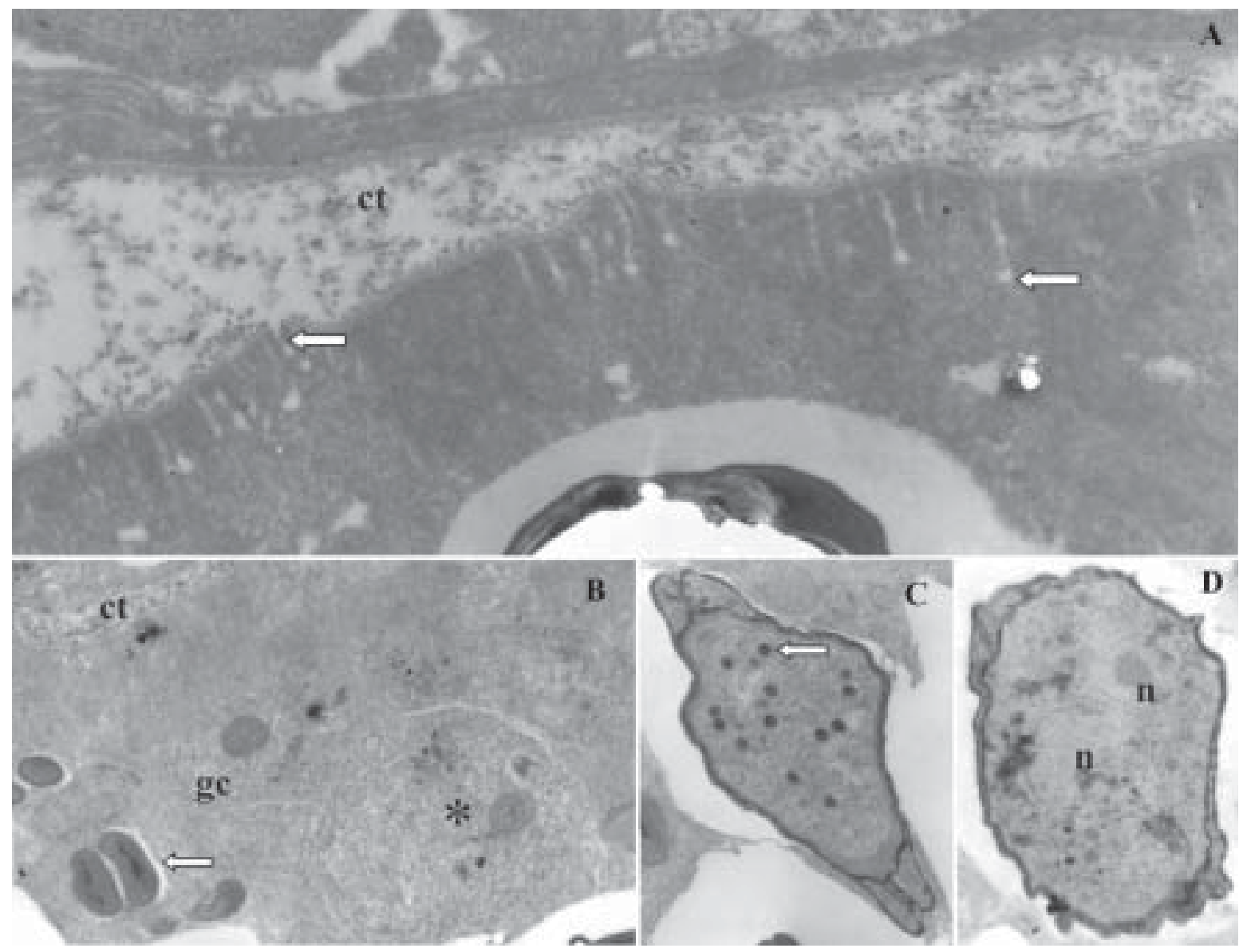

Fig. 2: electron micrographs of Henneguya caudalongula sp. n. from Prochilodus lineatus. A: section of the host-parasite interface showing the pinocytotic canals terminating in pinocytotic vesicles (arrows) and the capsule of connective tissue surrounding the plasmodium (ct). 19,200 ×; B: periphery of a plasmodium showing generative cell $(\mathrm{gc})$, spore in early developmental stage $(*)$, mature spores in the caudal level (arrow) and the capsule of connective tissue (ct). 10,680 $\times$; C-D: transversal sections of young spores in the sporoplasm level. C: showing the sporoplasmosomes (arrow). 10,850 ×; D: two nuclei (n). 12,930 ×. 


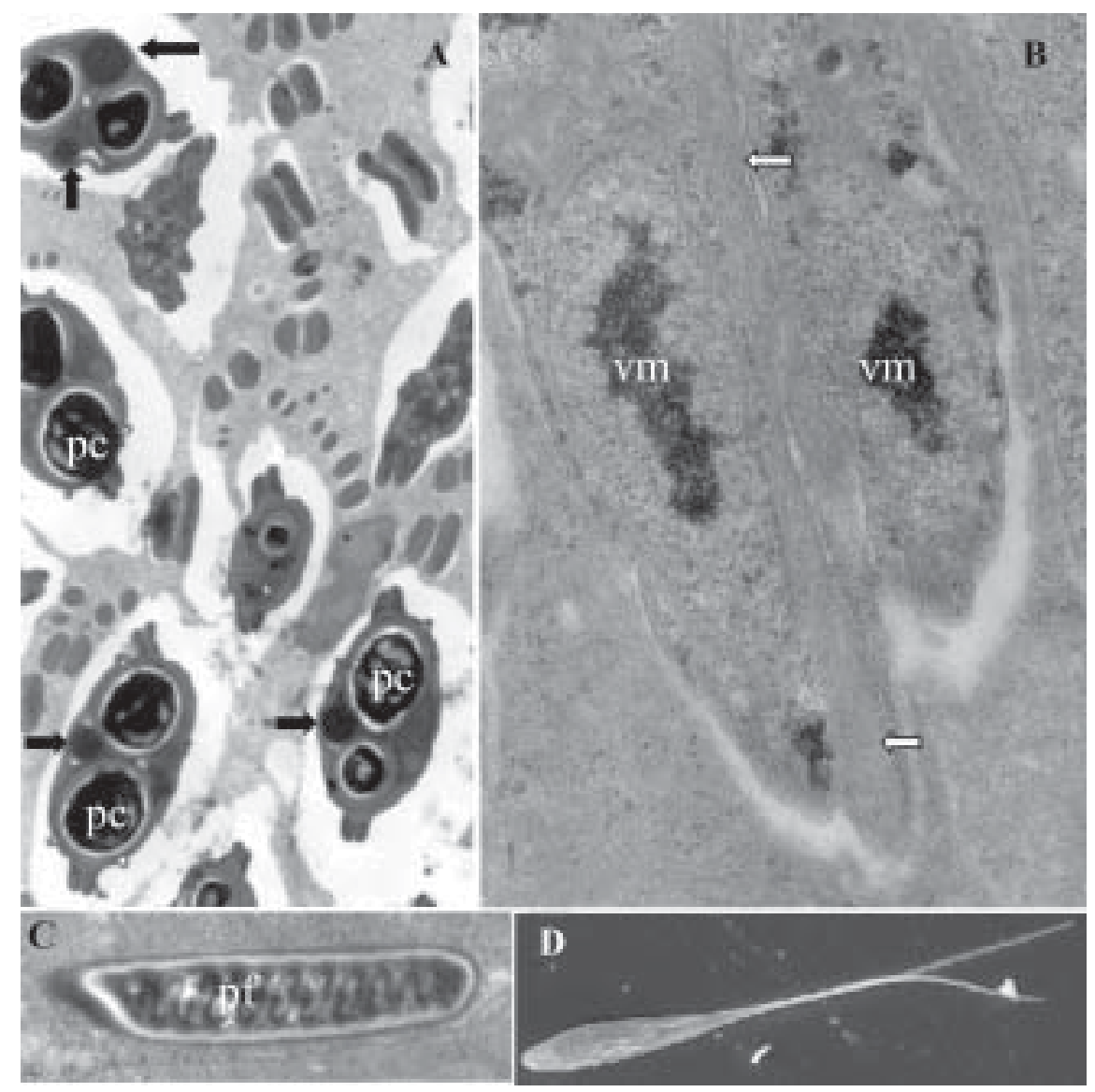

Fig. 3: electron micrographs of spores of Henneguya caudalongula sp. n. A: transversal sections of mature spores in the polar capsule (pc) level showing the electron-dense spherical inclusions (arrows). $6120 \times$; B: section of the tail showing longitudinal microtubules (arrows) and valve-forming material $(\mathrm{vm}) .28,670 \times$; C: longitudinal section of a polar capsule showing its polar filaments (pf). 14,000 ×; D: scanning electron image of a mature spore. $3730 \times$.

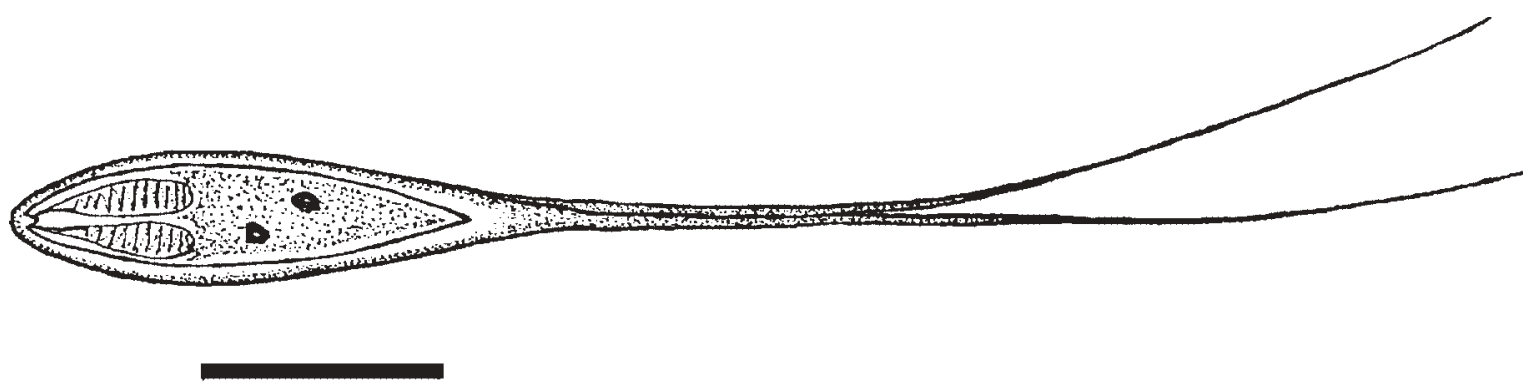

Fig. 4: schematic representation of mature spores of Henneguya caudalongula sp. $\mathrm{n}$. Bar $=10 \mu \mathrm{m}$.

TABLE

Comparison of the measurements $(\mu \mathrm{m})$ of spores from Henneguya caudalongula sp. n. with these of other species of Henneguya

\begin{tabular}{|c|c|c|c|c|c|c|c|c|c|c|}
\hline Species & $\mathrm{TL}$ & BL & $\mathrm{BW}$ & Tal & PCL & PCW & $\mathrm{FC}$ & Host & $\begin{array}{l}\text { Site of } \\
\text { infection }\end{array}$ & Reference \\
\hline H. caudalongula & 71 & 16.6 & 4.6 & 52.6 & 6.1 & 1.6 & $10-11$ & Prochilodus lineatus & Gills & This study \\
\hline H. piaractus & 52.5 & 12.7 & 3.6 & 41.2 & 6.7 & 1.2 & $8-9$ & Piaractus mesopotamicus & Gills & Martins \& Souza, 1997 \\
\hline H. pilosa & 54.2 & 21.1 & 5.9 & 33.1 & 7.4 & 1.2 & $11-12$ & Serrasalmus altuvei & Gills & Azevedo \& Matos, 2003 \\
\hline
\end{tabular}

TL: total length; BL: body length; BW: body width; Tal: tail length; PCL: polar capsule length; PCW: polar capsule width; FC: number of polar filament coils. 
trastructural analysis revealed a complex network of densely ramified granulo-fibrillar masses covering the spores of H. pilosa (Azevedo \& Matos 2003) and numerous spherical lipid droplets immersed in the sporoplasm cells of $H$. piaractus (Adriano 2004). These structures were not seen in $H$. caudalongula, but the spores of this species have electron-dense spherical inclusions located in the space between the polar capsules and valve. Similar structures have also been reported in $H$. pilosa (Azevedo \& Matos 2003).

H. caudalongula is the largest South American species of this genus described so far. Compared with Henneguya species from other geographical regions, the dimensions of its spores are smaller only than those of H. clariae Abolarin, 1971 (Nigeria), H. gigantea Nemeczek, 1911 (Hungary), H. pellis Minchew, 1977 (US), H. sebasta Moser et Love, 1975 (US), and H. tunghuensis Chen, 1998 (China) (Eiras 2002).

Ultrastructural analysis showed that sporogenesis in H. caudalongula differs from other Henneguya species (Current 1979, Azevedo \& Matos 2002, El-Mansy \& Bashtar 2002, Vita et al. 2003) by the presence of electrondense spherical inclusions located in the space between the polar capsules and valve, except for $H$. pilosa (Azevedo \& Matos 2003).

Of the chemical and physical properties of the water evaluated, only the dissolved oxygen level presented a weak correlation with the prevalence of $H$. caudalongula, but the prevalence did not vary significantly with season or host size. This finding indicate that the life cycle of this parasite is not influenced by environmental factors or host development, as also reported by Barassa et al. (2003) for H. chydadea Barassa, Arana et Cordeiro, 2003 infecting the gills of Astyanax altiparanae. In contrast, Molnár (1998) observed that the prevalence of $H$. creplini Gurley, 1894 varied with season and host size.

No important inflammatory response was observed in specimens of curimbatá infected by $H$. caudalongula, but a massive infection by this parasite could compromise the gill functions by deforming of the lamellar structures and reducting the gill area.

\section{ACKNOWLEDGMENTS}

To Dr Paulo S Ceccarelli (Cepta/Ibama) for assistance during this work and Dr Stephen Hyslop (Unicamp) for editing the English of the manuscript. This work is a part of a doctoral thesis by EA Adriano and was supported by Capes.

\section{REFERENCES}

Adriano EA 2004. Myxozoa em Peixes Autóctones Mantidos em Sistemas de Criação: Taxonomia e Relação Parasito- hospedeiro, $\mathrm{PhD}$ Thesis, Universidade Estadual de Campinas, Campinas, SP, 90 pp.

Adriano EA, Arana S, Ceccarelli PS, Cordeiro NS 2002. Light and scanning electron microscopy of Myxobolus porofilus sp. n. (Myxosporea: Myxobolidae) infecting the visceral cavity of Prochilodus lineatus (Pisces: Characiformes; Prochilodontidae) cultivated in Brazil. Folia Parasitol 49: 259-262.

Azevedo C, Matos E 2002. Fine structure of the myxosporean, Henneguya curimata sp. n., parasite of the Amazonian fish, Curimata inormata (Teleostei, Curimatidae). J Euk Microbiol 49: 197-200.

Azevedo C, Matos E 2003. Fine structure of Henneguya pilosa sp. n. (Myxozoa: Myxosporea), parasite of Serrasalmus altuvei (Characidae), in Brazil. Folia Parasitol 50: 37-42.

Barassa B, Arana S, Cordeiro NC 2003. A new species of Henneguya, a gill parasite of Astyanax altiparanae (Pisces: Characidae) from Brazil, with comments on histopathology and seasonality. Mem Inst Oswaldo Cruz 98: 761-765.

Current WL 1979. Henneguya adiposa Minchew (Myxosporida) in the channel catfish: ultrastructure of the plasmodium wall and sporogenesis. J Protozool 26: 209-217.

Eiras JC 2002. Synopsis of the species of the genus Henneguya Thélohan, 1892 (Myxozoa: Myxosporea: Myxobolidae). Syst Parasitol 52: 43-54.

El-Mansy A, Bashtar AR 2002. Histopathological and ultrastructural studies of Henneguya suprabranchiae Landsberg, 1987 (Myxosporea: Myxobolidae) parasitizing the suprabranchial organ of the freshwater catfish Clarias gariepinus Burchell, 1822 in Egypt. Parasitol Res 88: 617626.

Godoy MP 1975. Peixes do Brasil. Subordem Characidae, Bacia do Rio Mogi-Guassu, Franciscana, São Paulo, 847 pp.

Lom J, Arthur JR 1989. A guideline for the preparation of species description in Myxosporea. J Fish Dis 12: 151-156.

Martins ML, Souza VN 1997. Henneguya piaractus n. sp. (Myxozoa: Myxobolydae), a gill parasite of Piaractus mesopotamicus Holmberg, 1887 (Osteichthyes: Characidae), in Brazil. Rev Bras Biol 57: 239-245.

Molnár K 1998. Taxonomic problems, seasonality and histopathology of Henneguya creplini (Myxosporea) infection of the pikeperch Stizostedion lucioperca in Lake Balaton. Folia Parasitol 45: 261-269.

Vita P, Corral L, Matos E, Azevedo C 2003. Ultrastructural aspects of the myxosporean Henneguya astyanax sp. n. (Myxozoa: Myxobolidae), a parasite of the Amazonian teleost Astyanax keithi (Characidae). Dis Aquat Org 53: 55-60. 
